\title{
Les enfants de l'usure ou la procréation pervertie
}

\section{Wendy Ribeyrol}

\section{(2) OpenEdition}

\section{Journals}

Édition électronique

URL : http://journals.openedition.org/shakespeare/1251

DOI : 10.4000/shakespeare.1251

ISSN : 2271-6424

Éditeur

Société Française Shakespeare

Édition imprimée

Date de publication : 1 novembre 1993

Pagination : 69-80

Référence électronique

Wendy Ribeyrol, «Les enfants de l'usure ou la procréation pervertie », Actes des congrès de la Société française Shakespeare [En ligne], 11 | 1993, mis en ligne le 01 janvier 2007, consulté le 05 mai 2019. URL : http://journals.openedition.org/shakespeare/1251; DOI : 10.4000/shakespeare.1251

Ce document a été généré automatiquement le 5 mai 2019.

(C) SFS 


\section{Les enfants de l'usure ou la procréation pervertie}

Wendy Ribeyrol 